\title{
A Tribute to Dr. Edward Lloyd Bousfield, 1926-2016
}

\author{
Kathleen E. Conlan ${ }^{1,6}$, Marjorie A. Bousfield ${ }^{2}$, Ed A. Hendrycks ${ }^{1}$, Eric L. Mills ${ }^{3}$, Francis R. \\ $\mathrm{COOK}^{4}$, and Charles G. GRUCHY ${ }^{5}$
}

${ }^{1}$ Canadian Museum of Nature, P.O. Box 3443, Station D, Ottawa, Ontario K1P 6P4 Canada

${ }^{2}$ P.O. Box 102, Wolfe Island, Ontario K0H 2 Y0 Canada

${ }^{3}$ Department of Oceanography, Dalhousie University, 1355 Oxford Street, P.O. Box 15000, Halifax, Nova Scotia B3H 4R2 Canada

${ }^{4} 13078$ Land O'Nod Road, R.R. \#3, North Augusta, Ontario K0G IR0 Canada

${ }^{5} 6657$ Old Forest Drive, North Gower, Ontario K0A 2T0 Canada

${ }^{6}$ Corresponding author: kconlan@mus-nature.ca

Conlan, Kathleen E., Marjorie A. Bousfield, Ed A. Hendrycks, Eric L. Mills, Francis R. Cook, and Charles G. Gruchy. 2016. A tribute to Dr. Edward Lloyd Bousfield, 1926-2016. Canadian Field-Naturalist 130(4): 359-372.

Canadian scientist Edward Lloyd Bousfield died in Mississauga, Ontario on 7 September 2016 at age 90 (Figure 1). Ed was a world authority on the systematics of amphipod crustaceans. He discovered and described over 300 new species and has 18 species and two genera named in his honour with another to come (Table $1)$.

Ed joined the National Museum of Canada (with the natural sciences now in the Canadian Museum of Nature, CMN) in 1950 after obtaining his B.A. and M.A. degrees at the University of Toronto (1948 and 1949), and deciding on a career as a biologist, rather than a musician. He then earned a Ph.D. at Harvard University (1954) and, on the recommendation of John Dymond (1887-1964), Head of Zoology at the University of Toronto, applied to and was hired by CMN as Invertebrate Zoologist (1950-1963). Expecting to work for federal Fisheries or as a university professor, Ed considered that this move had a monumental impact on his career path. Ed said later, "It was a good thing I took the job. Thank heavens I did. I can't imagine a job that's given me more pleasure than this job. The director says, here's the money, here's the car, here's the staff, go do your job and turn in the report at the end of the year. I think that philosophy yields far better results than standing over somebody every five minutes".

In 1964, Ed was promoted to Chief Zoologist and in 1974 he became Senior Scientist. During his 36 years at CMN, Ed influenced the museum's outlook in many ways. Canadian Museum of Nature herpetologist Francis Cook says, "I am indebted to him for supporting my two-year educational leave for my Ph.D. though his patience with me wore out before I finally submitted my thesis and obtained the degree. But when I submitted the manuscript for museum publication, Ed served as in-house reviewer and recommended the museum publish it, backing up the positive comments of an outside reviewer".

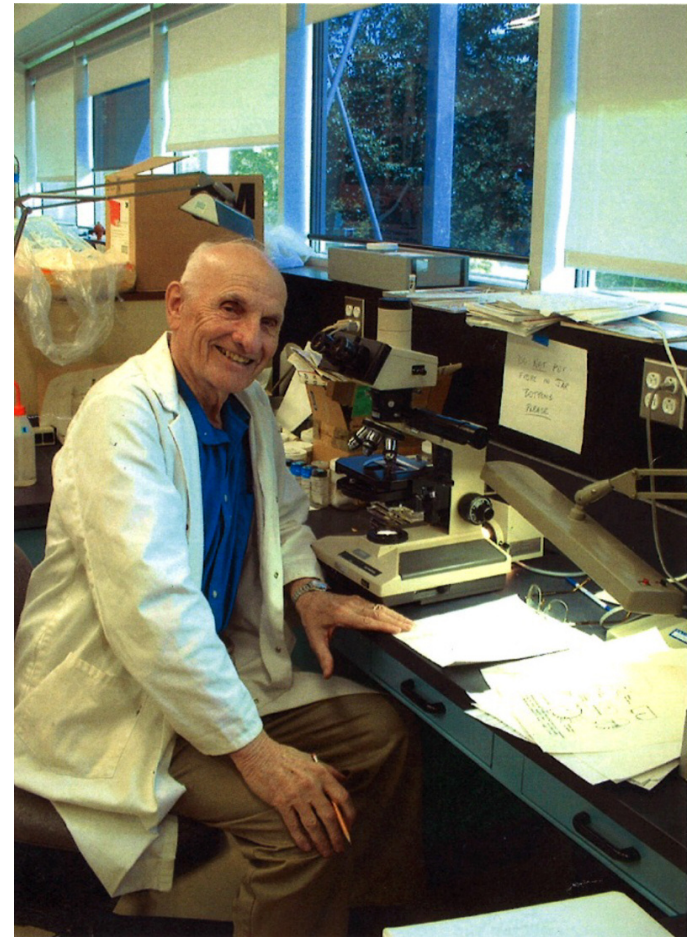

Figure 1. Ed reviewing illustrations in the Canadian Museum of Nature's new laboratories in the Natural Heritage Campus, Gatineau, Quebec. Photo: Ed Hendrycks (2010).

Ed's first years at CMN were spent in the Victoria Memorial Museum Building (VMMB) in downtown Ottawa, which also housed the National Art Gallery and the Geological Survey of Canada. After these organizations moved to new quarters in 1960, the VMMB became the headquarters for Nature and Man. Eventually, the nature collections became too large for the VMMB. 
TABLE 1. Species and genera named in honour of E. L. Bousfield, grouped by Order and Family. In brackets are the common name or description used by Ed. Classification follows the World Register of Marine Species (http://www.marinespecies.org/index .php).

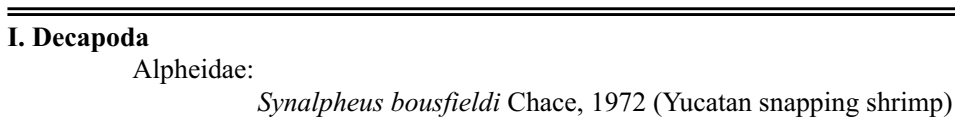

\section{Annelida}

Spionidae:

Scolelepis (Parascolelepis) bousfieldi Pettibone, 1963

\section{Amphipoda}

Stegocephalidae:

Bouscephalus Berge and Vader, 2001

Bouscephalus mamillidacta (Moore, 1992)

Bateidae:

Batea bousfieldi (Ortiz, 1991) (West Floridian single-cusped bateid)

Pontogeneiidae:

Paramoera bousfieldi Staude, 1995 (North Pacific shore shrimp)

Haustoriidae:

Acanthohaustorius bousfieldi Frame, 1980 (Western Atlantic sand shrimp)

Protohaustorius bousfieldi Robertson and Shelton, 1978 (Gulf States sand shrimp)

Stenothoidae:

Metopella bousfieldi Tzvetkova and Golikov, 1990 (Laptev Sea)

Liljeborgiidae:

Liljeborgia bousfieldi McKinney, 1979 (Gulf worm-tube commensal)

Colomastigidae:

Colomastix bousfieldi LeCroy, 1995 (West Floridian sponge commensal)

Crangonyctidae:

Crangonyx bousfieldi Zhang and Holsinger, 2003

Talitridae:

Bousfieldia Chou and Lee, 1996 (Type: Taiwanese landhopper)

Bousfieldia omoto Morino, 2014

Bousfieldia phoenixae Chou and Lee, 1996

Microrchestia bousfieldi Lowry and Peart, 2010

Platorchestia bousfieldi Hou and Li, 2003 (Chinese coastal landhopper)

Hadziidae:

Metaniphargus (Caribdzia) bousfieldi Stock, 1977 (Puerto Rican cave shrimp)

Maeridae:

Quadrivisio bousfieldi Karaman and Barnard, 1979 (Indo-Pacific 4-eyed scud)

Maera bousfieldi Krapp-Schickel and Jarrett, 2000

Melitidae:

Melita bousfieldi Garcia-Madrigal, 2010

Ischyroceridae:

Microjassa bousfieldi Conlan, 1995 (Northeastern Pacific thumb shrimp)

Pseudericthonius bousfieldi Souza-Filho and Serejo, 2014 
These, along with the science, exhibits, and administrative staff were gradually moved to 13 buildings around Ottawa, which resulted in an unhappily fragmented institution. While the invertebrate, bird, and mammal collections were in South Ottawa at Holly Lane, the library was down the road, botany, herpetology, ichthyology, and mineralogy were in West Ottawa, and paleobiology was in East Ottawa. Finally, in 1996, CMN was able to consolidate its labs and collections at its present-day Natural Heritage Campus in Gatineau, Quebec. Ed enjoyed this new setup even though he was by then retired, as it gave new opportunities to meet museum staff, reunite with colleagues, and enjoy some dynamic conversations at coffee breaks. Despite this massive move of over 10 million specimens, all of Ed's collections, photographs, and drawings were carefully preserved there and his collection information is now being digitized and will be online for public access.

Although Ed's doctoral work was on barnacles, he shifted to amphipods in the early 1950 s on the advice of his University of Toronto professor A.G. Huntsman (1883-1973), who felt that this group would open many research opportunities. This was sage advice as Ed subsequently spent most of his career studying amphipods, publishing papers from 1951 to 2012, although he also forayed into molluscs, publishing the useful Canadian Atlantic Seashells in 1960 followed by the French version in 1964 (Bousfield 1960, 1964). After his official retirement in November 1986, Ed continued his studies as Research Associate and Curator Emeritus at CMN, the Royal Ontario Museum in Toronto, and the Royal British Columbia Museum in Victoria.

Ed was pivotal to the twentieth-century growth of the CMN invertebrate collections through his widespread fieldwork and follow-up lab studies (Figure 2). JeanMarc Gagnon, current Curator of Invertebrates at CMN, estimates that $\mathrm{CMN}$ has about 48000 lots (single or group of specimens collected at one location) thanks to Ed's work. Not all of these are amphipods; his collections cover all sorts of invertebrates as well as four lots of birds, 57 herptiles, and more than 1000 fish. The large fish collection attributed to Ed came as a result of an extensive field trip in 1963 along the Alaskan coast with CMN ichthyologist Don McAllister (1934-2001; Coad 2010; Cook et al. 2010). This was a mutually useful collaboration as while Ed helped with the fish catch, the fish generated collections of amphipod prey from their gut contents and amphipod parasites from their skin and gills.

Immediately upon being hired by CMN, Ed was given a museum car and budget and told to get out into the field. For the next 30 years he embraced this work plan whole-heartedly, involving students, colleagues, and family in his program. In the two summers following their marriage in June 1953, Ed and his wife, Barbara (née Schwartz, d. 1983), a former technician for museum botanist Erling Porsild (1901-1977), worked together in the field (Figure 3). Beginning in 1958, Ed

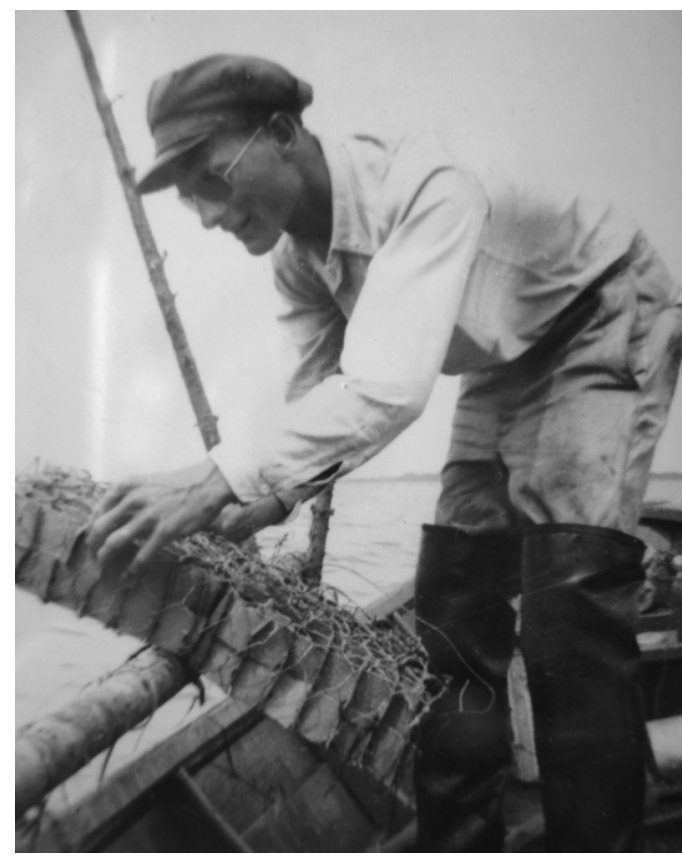

FiguRE 2. Ed collecting near Shippagan, N.B. (1947). Photographer unknown.

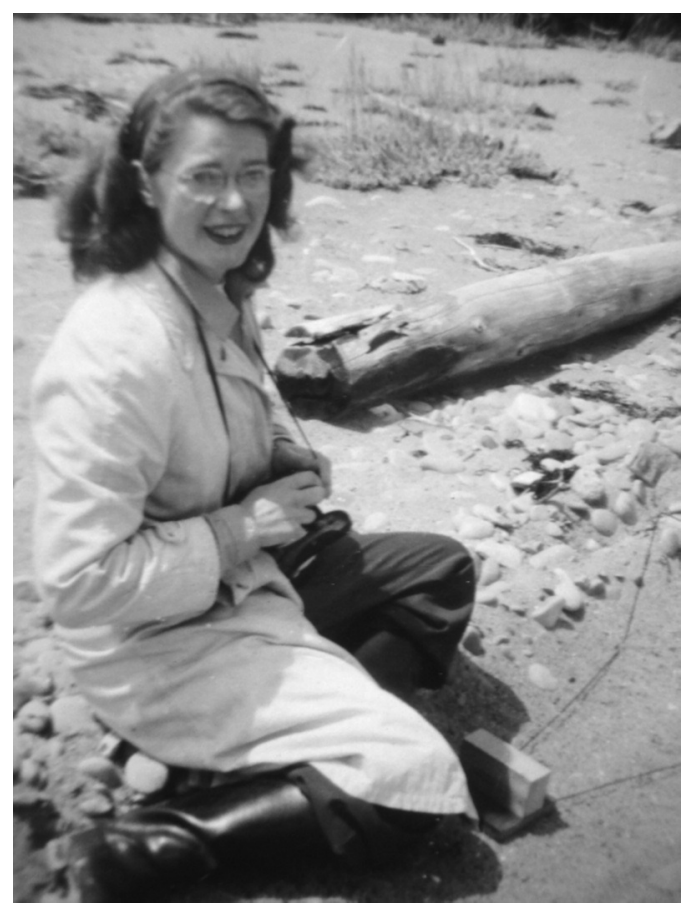

FIGURE 3. Barbara Bousfield as Ed's field assistant. Photo: Ed Bousfield (1953 or 1954). 
and Barbara's children (Marjorie, Kathy, Mary, and later, Ken) joined in the North American collecting expeditions, with the family living in a tiny rented Shasta trailer that Ed hauled on and off ferries, through steep mountain passes, and across seemingly endless prairies (Figure 4). Ed shared his love of this work with his children by having them take turns acting as his field assistants, once they reached school age or so. Getting out of bed in the dark coolness of an early morning to catch the low tide was not always something they wished to do, but once up, they enjoyed interesting adventures. "How many little kids could pronounce Dogielinotus, and know what it looked like, and the kind of beach on which it was to be found (along with the red "worms")?" laughed Ed. The remembered joy of this field work inspired daughter Marjorie to become a field biologist herself. In the last half hour of his life, Ed referred to these as "fun times".

Ed mentored over 40 students at 14 universities in Canada, 11 in the U. S. and internationally in Russia, Kuwait, France, Australia, and New Zealand. In a letter to CMN colleague Charles Gruchy, Ed said, "Hard to believe a government scientist could have broad university impact, but I lucked in with amphipods as a virtually unstudied but readily collectible aquatic inver- tebrate group, thanks mainly to A.G. Huntsman at U. of T.". Ed also maintained a key role in the Canadian Society of Zoologists, of which he was a 54-year member and President in 1979-1980. Other society involvements included the Crustacean Society, the Estuarine Research Federation, The Ottawa Field-Naturalists' Club, and The Brodie Club of Toronto. On his final presentation at The Brodie Club in April 2014, Ed made a detailed freehand drawing of an amphipod from memory.

Ed enjoyed reaching out to the general public and being involved in exhibits at the VMMB. Exhibit designer Asoka Weerasinghe wrote in condolence, "Dr. Bousfield, I was saddened to hear that you have left us. Thanks for your wisdom that you shared with me when putting together the Animal Life 3 and 4 Halls in the early 1970s at the Victoria Memorial Museum in Ottawa. It was a joy to have had the opportunity to work with you and come to know you as a special human being".

Ed's enthusiasm for natural history spread beyond museum doors to the children's Macoun Field Club and the parent The Ottawa Field-Naturalists' Club, where he held various executive positions. He would often lead dip-netting excursions to Ottawa-area rivers and lakes

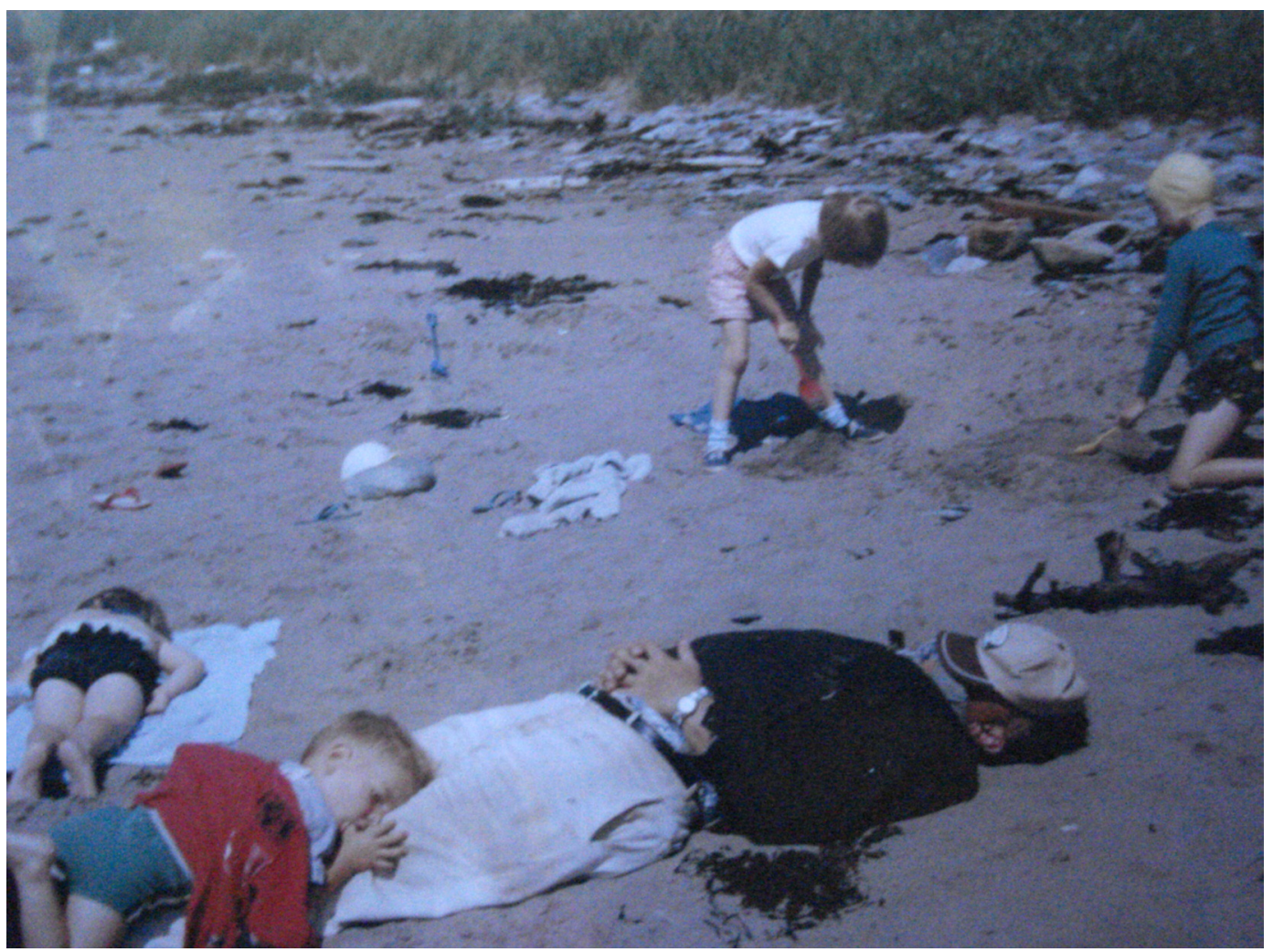

FIGURE 4. Ed and his younger children taking a break from early morning collecting while the elder two children may be continuing the search for amphipods. Photo: Barbara Bousfield (about 1964). 
(Figure 5). A former Macouner, Alice Smeathers, wrote that "we children were always so impressed by the fact that scientists would give up their Saturday mornings to spend with us. The club led me to a lifelong interest in natural science. I used my interest in teaching Elementary School and as a Girl Guide leader and now with my grandchildren. Bless you Dr. B.". Professor Emeritus Eric Mills of Dalhousie University met Ed through the Macoun Field Club, and became his field assistant. He writes that "the two summers, 1955 and 1957, that I spent with Ed in B.C. (and some points south) would make an essay in themselves, showing how the young Bousfield operated, and the kind of effect that could have on a 19-year-old just graduated from high school". This shows "... in just one example how important The Club was in encouraging young naturalists into scientific careers". Macoungraduate Susan Laurie-Bourque became Ed's artist for many of his publications, later illustrating for numerous other scientists at $\mathrm{CMN}$ and abroad.

Ed's interests were also artistic. As a young teen, Ed had written and illustrated fictional nature stories for a young-naturalists' publication in Toronto. His artistic ability continued through his working life in collaboration with Susan and earlier artists Floy Zitten, Ruth von Arx, and Charles Douglas (1923-2004; Bousfield and Cook 2012). Ed was adept at arranging music and playing musical instruments. He played trumpet into his seventies and guitar until 2014. He played in swing bands as a youth and the Salvation Army band as a near-senior and sang Barbershop in between. In his later years, he was a member of the "Aged in Harmony" senior men's musical group of Ottawa, the "Songsters" group at Somerset House in Victoria, B.C., and co-founder of the "Victoria Melody Makers" swing orchestra. Ed was also a great sports fan, particularly of ping-pong where his noon games at CMN with ornithologist Earl Godfrey (1910-2002) were legendary. Outside the museum, he was a fivepin bowler, curler (Figure 6), and lawn bowler.

From 1963 to 1970, Ed published a valuable series of taxonomic treatments of Atlantic coast amphipods. He collaborated with Groupe interuniversitaire de recherches océanographiques du Québec, making collections in the St. Lawrence estuary, and he was a Senior Visiting Investigator at the Woods Hole Marine Biological Laboratory on Cape Cod. This culminated in the book Shallow-water Gammaridean Amphipoda of New England (Bousfield 1973). Despite the regional title, this treatise covered amphipods that spanned the length of the U.S. and Canadian Atlantic coasts, making it of immense value to taxonomists and ecologists world-wide.

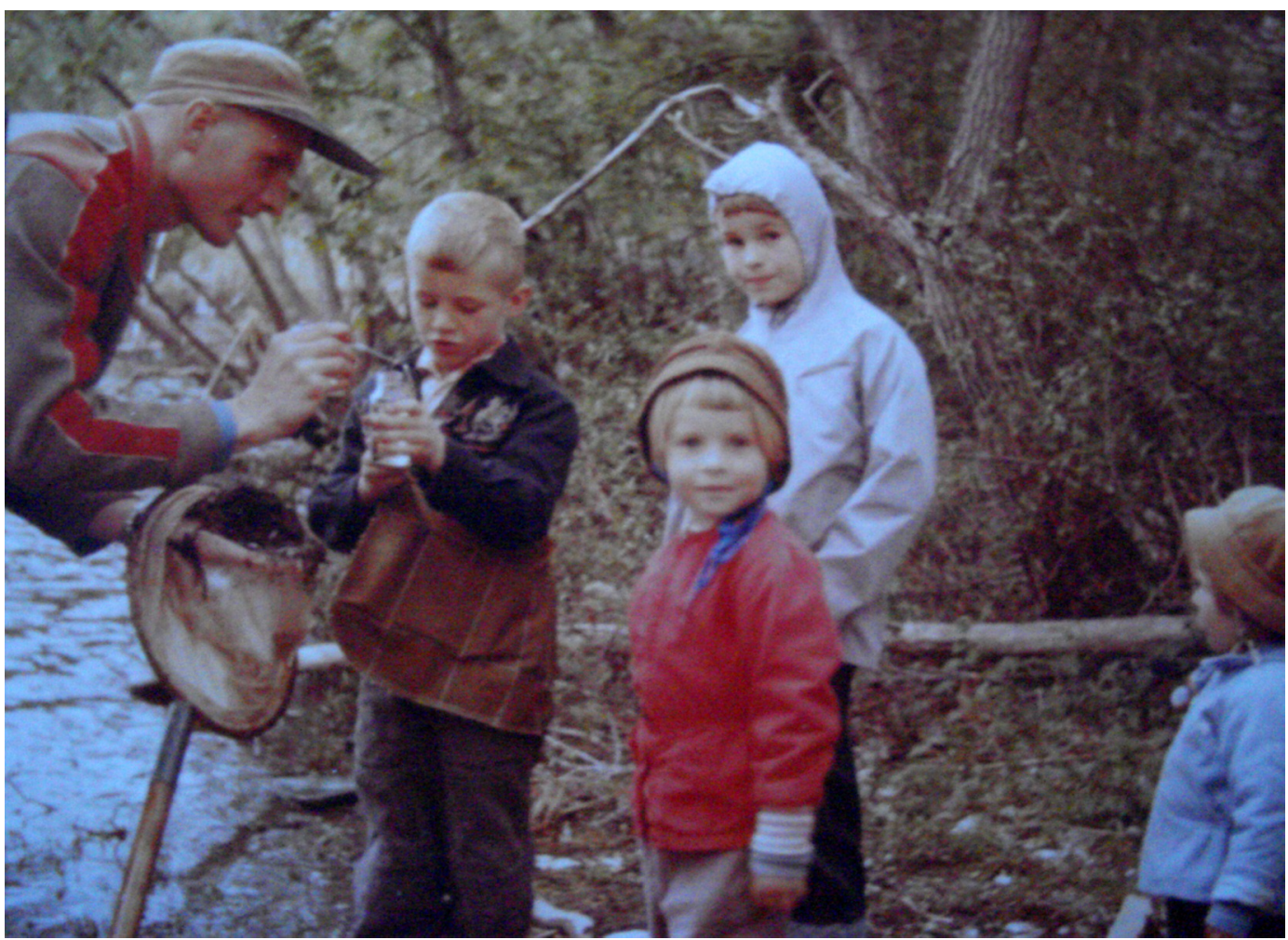

FIGURE 5. Ed dip-netting with children from the Macoun Field Club. Photo: Barbara Bousfield (1959). 

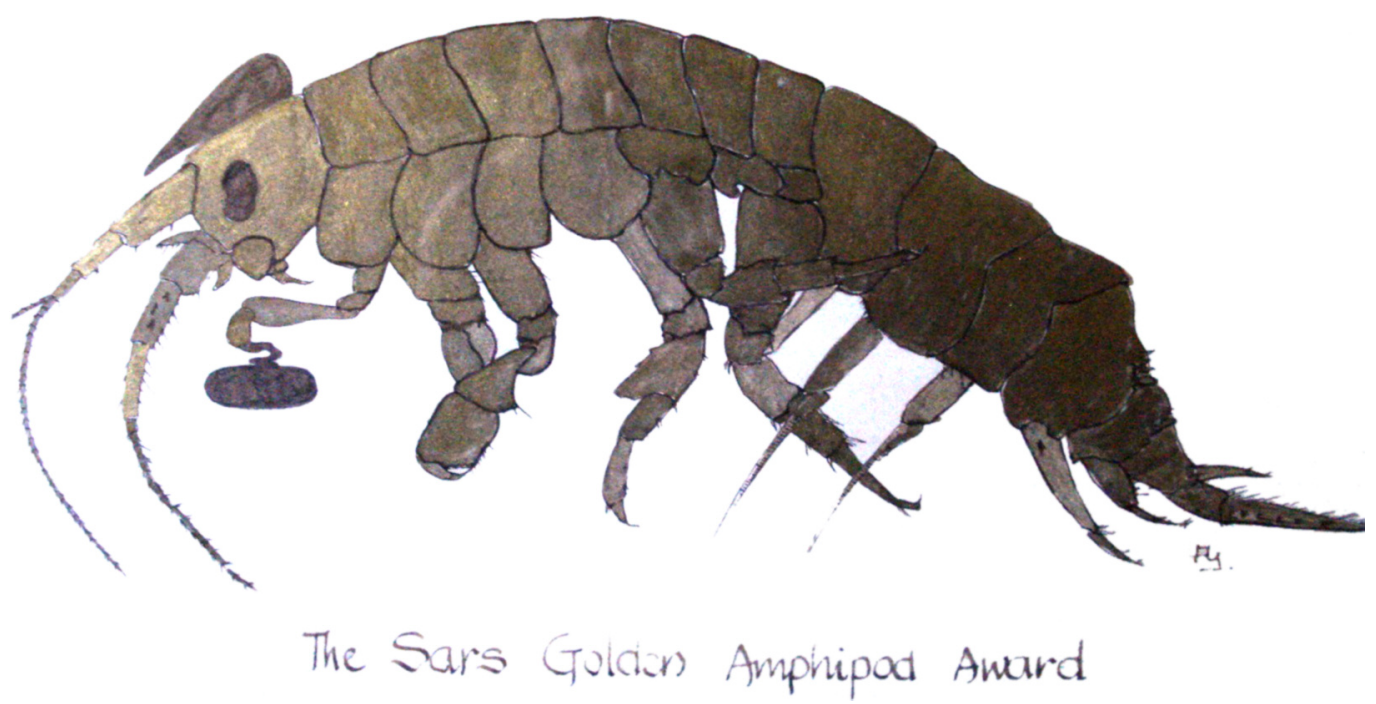

FIGURE 6. A special presentation to Ed from artist Floy Zitten, noting Ed's prowess with curling. The title of the award refers to scientist Georg Sars (1837-1927), whose skilled drawings and keen observations produced treatises that every amphipod taxonomist relies on today. Photo: Marjorie Bousfield (2016).

Following the success of his Atlantic coast research, Ed turned his attention fully to the Pacific and soon realized that this was a much more diverse coast, with numerous undescribed species. Ed's collecting expeditions extended from Alaska to northern California with Marjorie Bousfield, Kathy Conlan, John Dickinson, Peter Frank, Norma Jarrett, Ron Long, Eric Mills, and Fahmida Rafi (1933-2008) as assistants (Figure 7). When his family was in tow, Ed worked without an official assistant. Ed was open to bringing women along on field trips. CMN colleague Jacqueline Madill recalls, "When I applied for a position to work at the former National Museum of Natural Sciences he challenged me during the job interview, concerned that I was too petite and feminine to lift heavy objects and participate in field work. This was in an era when only male scientists had been allowed to participate in field work at our Museum and research in laboratories was dominated by male colleagues. After I described activities that I had participated in to illustrate what I could do, he listened not only politely but in an open and inviting manner. When I was hired, I have been forever grateful that Ed was able to allow for change".

Ed took advantage of his western trips to visit marine labs such as Friday Harbor Laboratories and Bamfield Marine Science Centre and give field courses and lectures. He also conducted workshops through the Southern California Association of Marine Invertebrate Taxonomists and pioneered the use of common names for amphipods (McLaughlin et al. 1995).

An unexpected result of the Pacific coast research was a delving into the Russian language by Ed, and much later, Marjorie. This was necessitated by the common distribution of many North Pacific amphipods on Russian, Alaskan, and British Columbian coasts. The works of Russian amphipodologists Yevpraxiva Fyodorovna Gurjanova (1902-1981) and Nina Liver'evna Tzvetkova (1932-2010) were essential to interpreting amphipod biogeography and taxonomy in the North Pacific, and so Ed took several Russian courses in the early 1960s. It was while cutting and pasting sections of Gurjanova for Ed in the mid-1970s that Marjorie first became interested in the Russian language. Subsequently, she too studied Russian, and translated for Ed many taxonomic descriptions. Despite the constraints of travel to the U.S.S.R., Ed was able to collaborate with Tzvetkova, resulting in a taxonomic treatment in Russian (Bousfield and Tzvetkova 1982).

Ed's focus on the Pacific Northwest influenced the career paths of many collaborators. His first field assistant, Eric Mills, was converted from ornithology to marine biology by Ed, and spent some years at Queen's and Dalhousie as an amphipod taxonomist. While Mills worked in the Museum laboratory in 1959-1960 as Ed's assistant, Ed encouraged him to work up some of the B.C. species from 1955 and 1957, publishing as sole author (Mills 1961, 1962), as well as his bird observations (Mills 1960a,b). Not only did he become a prolific amphipod expert and ecologist, Mills also published on the history of science, especially marine science, a subject dear to Ed's heart. Assistant Fahmida Rafi sorted and catalogued numerous collections for Ed and then moved within CMN to the challenge of isopod taxonomy (e.g., Rafi 1985; Rafi and Laubitz 1990). 


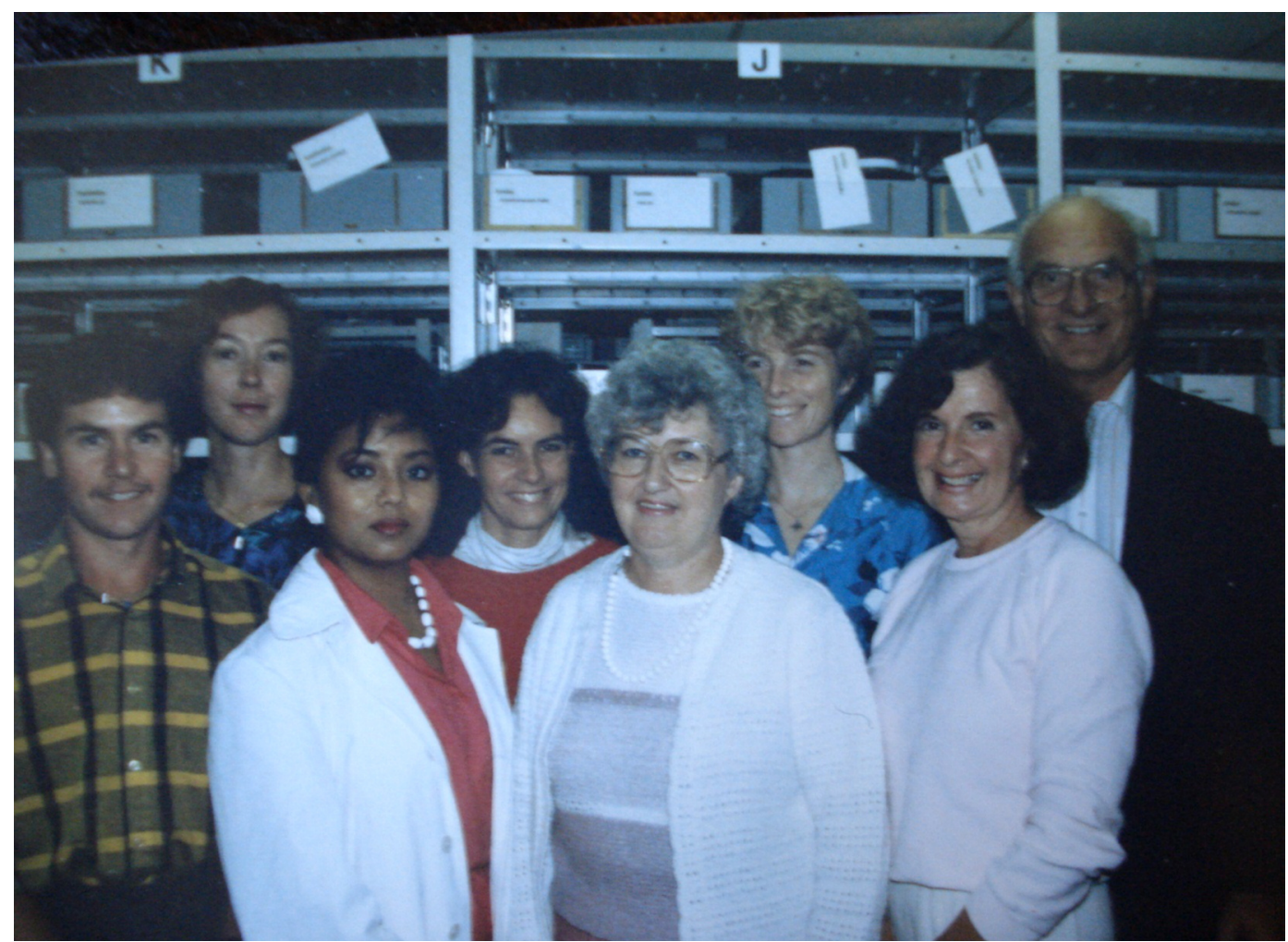

Figure 7. Ed's "Amphipod Unit” in Summer 1986. Left to right, Ed Hendrycks, Susan Laurie-Bourque, Karen Hahn, Kathy Conlan, Elemae Lashley, Marjorie Bousfield (visitor), Norma Jarrett, and Ed Bousfield. Photographer unknown; permission granted from Canadian Museum of Nature.

Norma Jarrett, who began as a CMN Volunteer, spent over two decades with Ed and became a competent amphipod taxonomist and co-author (Jarrett and Bousfield 1982, 1994a,b, 1996). CMN colleague Diana Laubitz became an authority on caprellid and podocerid amphipods (e.g., Laubitz 1979, 1993). John Dickinson came to Ed as a two-year post-doc and worked up the Pacific coast ampeliscids (Dickinson 1982, 1983). Hiroshi Morino came from Japan as a visiting scientist to further trans-Pacific studies (Bousfield and Morino 1992). Later, Ed was honoured with the dedication of a new species by Morino (Table 1).

Despite such an intensive focus on the Pacific Northwest, Ed's hoped-for book never materialized. The extraordinary diversity of the amphipods on this coast required more resources and time than anyone could have expected. However, there were fortunate outcomes of the Pacific coast project. Ed, with the help of CMN executives Charles Gruchy and Steven Cumbaa, launched the careers of Ed Hendrycks and Kathy Conlan at CMN, where they still work today.

Hendrycks helped move the Pacific coast project forward with taxonomic treatments on talitrids, pleustids, and eusirids (Bousfield and Hendrycks 1994 a,b, 1995 a,b, 1997, 2002; Hendrycks and Bousfield 2001,
2004). Hendrycks considers Ed "an amphipod legend, one of the BIG GUNS so to speak". Hendrycks recounts: "I remember vividly the day in 1983 that I met Ed. I was terrified, nervous but also excited at meeting a famous government scientist and entered his office at 2378 Holly Lane in Ottawa. He was seated behind his large desk, surrounded by reprint boxes and books. He was an intimidating man, but very quickly made me feel comfortable. He explained his research to me, showed me some amphipods and asked whether I could draw well. I said I think I can and showed him some pencil drawings I had done of beetles. Apparently this satisfied him, as within a few days I was hired on a contract! That was the start of my career as an amphipodologist at the museum. Ed had very set methods in which he conducted particular aspects of his amphipod research and one of them in particular stuck with me. While most taxonomists made multiple slide mounts from their dissected specimens (some more than 10 per amphipod), Ed was adamant that he preferred only one! The slide was made the same way each time, with the appendages in the same orientation. In this way, he could rapidly "compare" two slides by stacking one on top of the other under the stereoscope, as the appendages would be close to the same position. I have con- 
tinued to adopt Ed's technique to this day! I will forever be grateful to Ed for hiring me that day and launching my career. He was larger than life and I will miss him always".

Kathy Conlan's contribution to the Pacific coast project was taxonomic review of amphithoids, aorids, isaeids, and ischyrocerids (Conlan 1982, 1983, 1988, 1990; Conlan and Bousfield 1982 a,b). Ed's broad understanding of the evolution and behaviour of amphipods helped her understand the effect of sexual selection and how sexually selected characters could be unreliable taxonomic traits (Conlan 1989, 1991). Conlan attributes Ed's deep love of discovery and his immense breadth of knowledge of crustacean phylogeny, behaviour, physiology, and ecology to be her inspiration to look beyond morphology to functionality.

Ed was patient with his assistants and generous with his time. When Conlan was first learning amphipod morphology, she asked Ed in frustration how she could recognize when a specimen was a juvenile of one species rather than an adult of some other, small-bodied species. "Oh," said Ed (with a smile), "juveniles just have that baby-faced look". That was a puzzling answer, but in time, Conlan could see what he meant and went on to use the same cryptic descriptor with her students.

Ed was also generous with his authorships. Colleague Jim Carlton, now Emeritus Professor of Marine Sciences at Williams College in Massachusetts, recalls vividly his correspondence with $\mathrm{Ed}, 50$ years ago in 1966. At the behest of Jerry Barnard, Jim sent specimens of a talitrid from San Francisco Bay to Ed for identification; given Ed's deep familiarity with this group from the California coast, Ed immediately recognized it as something special ("To say that this material is interesting would be an understatement", Ed wrote to Jim that fall). Ed deduced it was likely a non-native but undescribed species, and wrote the paper and prepared the figures. Jim contributed, in the form of letters, information on other exotic species in the Bay, and habitat data. Most scientists would have simply put Jim in the acknowledgements - instead, Jim writes, "Ed, the gentleman and scholar that he was, very generously made me a co-author on what was to be my first peer-reviewed paper!" (Bousfield and Carlton 1967). It was to be years later that Ed learned that Jim was 18 years old at the time - but that would have made no difference to Ed.

Many studies by Ed and collaborators were published in-house. When this unit was closed after an extensive re-organization at CMN in 1991, Ed found that there were no other publishers of large taxonomic treatments. This situation could have been the death knell for Ed's goal of a Pacific coast guidebook, but, undaunted, Ed put forward his personal funds to develop the journal Amphipacifica. This ran from 1994 to 2004 and became the vehicle for both himself and his colleagues to get new species descriptions, taxonomic revisions, and reviews of biogeography and evolution into the scientific literature.

Besides his intensive focus on the Atlantic and Pacific coasts of North America, Ed collected amphipods in the Caribbean, Australia, and South America. One of his more memorable findings was of hypogean talitrid amphipods in a lava tube on the island of Kauai (Hawaii; Bousfield and Howarth 1979). Another spectacular find occurred on a boat cruise on Lake Baikal (Russia) where he was invited to bring back to CMN a beautiful sponge covered in spiny amphipods. Perhaps his most memorable expedition was the historic circumnavigation of the Americas by CSS Hudson in 1969-1970. Ed participated in the leg of the voyage from Buenos Aires to Santiago. With an assistant and small boat, Ed worked along famous Beagle Channel, making collections that included what was described in the press as the amphipod equivalent of a dinosaur.

Ed was proud of his discovery of a credible basis for organizing amphipod taxa into superfamilies (Bousfield 1977, 1978), a re-classification that has stood the test of time. He became particularly interested in the use of specialized organelles, such as calceoli, presumed vibration sensors that form on the antennae of species that tend to mate freely in the water column. Ed's broad understanding of the evolution of the Amphipoda extended to the Crustacea as a whole, both extant and fossil. He had a keen interest in the curious crustaceans of the Burgess Shale (Bousfield 1995) and had many good discussions on crustacean evolution with colleagues Waldo Schmitt (1887-1977; U.S. National Museum) and Frederick Schram (the Universiteit van Amsterdam, the Netherlands).

Not afraid of conflict, Ed viewed amphipod relationships through a different lens than contemporaryamphipodologist Jerry Barnard (1928-1991) at the U.S. National Museum. This made conference attendance entertaining for colleagues of the two, and no doubt spurred both scientists to greater heights. Ed and colleague Craig Staude wrote a special tribute to Barnard in Ed's first issue of Amphipacifica after Barnard's early death (Bousfield and Staude 1994). Colleague Wim Vader of the University Museum of the University of Tromsø in Norway feels that "Ed's death really signifies the end of an era in amphipod taxonomy, and not only in Canada, but everywhere. Ed had a very sharp eye for both differences and relationships among the amphipods; it was often possible to disagree with him, although not easy, as Ed was especially thin-skinnedto criticism; but his opinions were always well worth listening to and studying, and were only neglected at your peril".

Ed's interests broadened even further after 1992 when he moved to Victoria and married his third wife, Joyce Burton (née Bradley, d. 2009) following a brief marriage to Margaret Tuer (neé Ainslie) in the mid1980s. Living not far from Cadboro Bay, Ed became interested in the elusive mega-serpent, Cadborosaurus. 
With Paul LeBlond of the University of British Columbia, Ed formalized it as a new genus and species, Cadborosaurus willsi (Bousfield and LeBlond 1995), and wrote a popular book about it (LeBlond and Bousfield 1995). Ed was convinced that "Caddy" existed, rueing the misinterpretation of the type specimen as whale offal and its long-ago disposal, leaving only grainy photographic evidence. CMN colleague Francis Cook, who reviewed their book (Cook 1995), says, "I always admired Ed for his ingenuity in blending so many anecdotal reports into a life history of the beast, but always maintained the need for a fresh specimen and not dependence on fuzzy photographs of a discard if recognition of its existence was to be validated and generally accepted". Ed enjoyed the scepticism and enthusiasm he received along with the numerous requests for talks and interviews. He was, as CryptoNews stated, "a daring zoologist" for even considering a subject that most scientists simply dismissed.

In 1999, Ed and Joyce returned to Ottawa and then the Toronto area, where they could be closer to Joyce's family. This return to Ontario also brought about a closer relationship with $\mathrm{CMN}$, enabling Ed to launch new amphipod projects. Ed's ultimate goal was to produce a book, The Amphipods of Canada, which would comprise over 1000 species, he estimated. With that in mind he launched into a taxonomic treatment of holarctic pontoporeiids. As with other North American amphipod groups, Ed discovered that a group seemingly consisting of fewer than 10 species actually comprised many more, in this case $40+$ species in eight genera, mostly new to science. The unending mushrooming of the group prevented Ed from publishing his revision before he became too ill to continue the work. Ed quipped that "only about half a dozen amphipod people...have tackled this group seriously during the past $170+$ years. The others were apparently too smart to get involved!".

In 1978, Ed was elected Fellow of the Royal Society of Canada and, in 1985, he received the Government of Canada's Outstanding Achievement Award. In 1986, he was made Honorary Member of the Ottawa Field Naturalists' Club and in 1992, Honorary Member of the Canadian Society of Zoologists. Never interested in full retirement, Ed remained an active Emeritus Scientist at CMN. In an interview in 2016, Ed said, "One thing I can't believe is the amount of international recognition you get. Even now, at age $90 \ldots$ I am still getting emails from people who are interested in what I did!" and "My best life-long friends were scientists, because they had the same aims in life as I had".

When colleague Eric Mills gave Ed a copy of his latest book in Ottawa not all that long ago, he wrote inside "To Ed Bousfield, mentor and friend". "I know that Ed was touched by this", said Eric. "And now I can see clearly that the same thing could have been written by so many of the people that he worked with". Col- league Wim Vader says that he "... was always struck about how eager Ed still was to learn more and to understand the taxonomy and relationships, as well as the functional morphology, of his beloved animals". "Those amphipods." Ed would say, "You can never beat them into submission. There's always another new species around the corner, just when you think you're done". Ed Bousfield leaves us an immense collection full of many more species to discover and an incomparable legacy of encouragement to others.

\section{Acknowledgements}

We wish to thank the following for their contributions: Jim Carlton, Chantal Dussault, Jean-Marc Gagnon, Mark Graham, Jacqueline Madill, Alice Smeathers, Wim Vader, and Asoka Weerasinghe. Some of the information in this article derives from an interview that Ed Bousfield gave on 22 January 2016 to Mark Graham (Vice President, Research and Collections, CMN), from the Obituary for Edward Lloyd Bousfield published in the Ottawa Citizen on 15 September 2016 and from an interview with Ed Bousfield published in Amphipod Newsletter 37: 2-6 (2013).

Web link for Ottawa Citizen:

Canadian Cremation http://www.canadiancremation .com/book-of-memories/2707457/Bousfield-Edward /service-details.php. Accessed: 10 January 2017.

Web link for Amphipod Newsletter: http://www. marinespecies.org/amphipoda/newsletters/Amphipod Newsletter-37 2013.pdf. Accessed 4 January 2017.

\section{Literature Cited}

Bousfield, E. L. 1960. Canadian Atlantic Sea Shells. National Museum of Canada, Ottawa, Ontario, Canada.

Bousfield, E. L. 1964. Coquillages des Côtes Canadiennes de l'Atlantique. Musée national du Canada. Ottawa, Ontario, Canada.

Bousfield, E. L. 1973. Shallow-water Gammaridean Amphipoda of New England. Cornell University Press, Ithaca, New York, USA.

Bousfield, E. L. 1977. A new look at the systematics of gammaroidean amphipods of the world. Crustaceana Supplement 4: 282-316.

Bousfield, E. L. 1978. A revised classification and phylogeny of amphipod crustaceans. Transactions of the Royal Society of Canada, Series 4 16: 343-390.

Bousfield, E. L. 1995. A contribution to the natural classification of Lower and Middle Cambrian arthropods: foodgathering and feeding mechanisms. Amphipacifica 2(1): 3-34.

Bousfield, E. L., and J. Carlton. 1967. New records of Talitridae (Crustacea: Amphipoda) from the central California coast. Bulletin of the Southern California Academy of Sciences 66: 277-284.

Bousfield, E. L., and F. R. Cook. 2012. A tribute to Charles Hogg Douglas, 1923-2004. Canadian Field-Naturalist 126: 164-166.

Bousfield, E. L., and E. A. Hendrycks. 1994a. A revision of the family Pleustidae (Amphipoda: Gammaridea). Part 1. Systematics and biogeography of component subfamilies. Amphipacifica 1(1): 17-57. 
Bousfield, E. L., and E. A. Hendrycks. 1994b. The Amphipod superfamily Leucothoidea on the Pacific coast of North America. Family Pleustidae: Subfamily Pleustinae. Systematics and Biogeography. Amphipacifica 1(2): 3-69.

Bousfield, E. L., and E. A. Hendrycks. 1995a. The amphipod family Pleustidae on the Pacific Coast of North America. Part 3. Subfamilies Parapleustinae, Dactylopleustinae and Pleusirinae: systematics and distributional ecology. Amphipacifica 2(1): 65-133.

Bousfield, E. L., and E. A. Hendrycks. 1995b. The amphipod superfamily Eusiroidea in the North American Pacific region. 1. Family Eusiridae: systematics and distributional ecology. Amphipacifica 1(4): 3-59.

Bousfield, E. L., and E. A. Hendrycks. 1997. The amphipod superfamily Eusiroidea in the North American Pacific region. 2. Family Calliopiidae: systematics and distributional ecology. Amphipacifica 2(3): 3-66.

Bousfield, E. L., and E. A. Hendrycks. 2002. The talitroidean amphipod family Hyalidae revised, with emphasis on the North Pacific fauna: systematics and distributional ecology. Amphipacifica 3(3): 17-134.

Bousfield, E. L., and F. G. Howarth. 1979. The cavernicolous fauna of Hawaiian lava tubes 8. Terrestrial Amphipoda (Talitridae), including a new genus and species with notes on its biology. Pacific Insects Monography 17(1): 144-154.

Bousfield, E.L., and P. H. Leblond. 1995. An account of Cadborosaurus willsi, new genus, new species, a large aquatic reptile from the Pacific coast of North America. Amphipacifica 1(suppl. 1): 3-25.

Bousfield, E. L., and H. Morino. 1992. The amphipod genus Ramellogammarus in fresh waters of western North America: systematics and distributional ecology. Contributions to Natural Science 17: 1-21.

Bousfield, E. L., and C. P. Staude. 1994. The impact of J. L. Barnard on North American Pacific amphipod research: a tribute. Amphipacifica 1(1): 3-16.

Bousfield, E. L., and N. L. Tzvetkova. 1982. K izucheniju Dogielinotidae (Amphipoda, Talitroidea) iz pribrezhnykh vod severnoj chasti Tikhogo okeana [Studies on Dogielinotidae (Amphipoda, Talitroidea) from the shallow waters of the North Pacific Region]. Issledovanija Fauny Morej / Zoologicheskij Institut, Akademija Nauk SSSR 29(37): 76-94.

Conlan, K. E. 1982. Revision of the gammaridean amphipod family Ampithoidae using numerical analytical methods. Canadian Journal of Zoology 60: 2015-2027.

Conlan, K. E. 1983. The amphipod superfamily Corophioidea in the Northeastern Pacific region. Family Isaeidae. Systematics and distributional ecology. National Museum of Natural Sciences (Ottawa). Publications in Natural Sciences 4: $1-75$.

Conlan, K. E. 1988. Phenetic and cladistic methods applied to a small genus (Corophioidea: Ischyroceridae: Microjassa) and a larger outgroup. Crustaceana, Supplement 13: 143-166.

Conlan, K. E. 1989. Delayed reproduction and adult dimorphism in males of the amphipod genus Jassa (Corophioidea: Ischyroceridae): an explanation for systematic confusion. Journal of Crustacean Biology 9: 601-625.

Conlan, K. E. 1990. Revision of the crustacean amphipod genus Jassa Leach (Corophioidea: Ischyroceridae). Canadian Journal of Zoology 68: 2031-2075.

Conlan, K. E. 1991. Precopulatory mating behavior and sexual dimorphism in the amphipod Crustacea. Hydrobiologia 223: 255-282.
Conlan, K. E., and E. L. Bousfield. 1982a. The amphipod superfamily Corophioidea in the Northeastern Pacific region. Family Ampithoidae: systematics and distributional ecology. National Museum of Natural Sciences (Ottawa). Publications in Biological Oceanography 10: 41-75.

Conlan, K. E., and E. L. Bousfield. 1982b. The amphipod superfamily Corophioidea in the Northeastern Pacific region. Family Aoridae: systematics and distributional ecology. National Museum of Natural Sciences (Ottawa). Publications in Biological Oceanography 10: 77-101.

Coad, B. W. 2010. Bibliography of Donald Evan McAllister. Canadian Field-Naturalist 124: 336-356.

Cook, F. R. 1995. Cadborosaurus: survivor from the deep. Canadian Field-Naturalist 109: 498-499.

Cook, F. R., B. W. Coad, C. B. Renaud, C. G. Gruchy, and N. R. Alfonso. 2010. Donald Evan McAllister, 1934-2001: the growth of ichthyological research at the National Museum of Canada/Canadian Museum of Nature. Canadian FieldNaturalist 124: 330-335.

Dickinson, J. J. 1982. The systematics and distributional ecology of the family Ampeliscidae (Amphipoda, Gammaridea) in the North-eastern Pacific region. I. The genus Ampelisca. National Museums of Canada, Publications in Biological Oceanography 10: 1-39.

Dickinson, J. J. 1983. The systematics and distributional ecology of the superfamily Ampeliscoidea (Amphipoda, Gammaridea) in the Northeastern Pacific region. II. The genera Byblis and Haploops. National Museum of Canada, Publications in Natural Sciences 1: 1-38.

Hendrycks, E. A., and E. L. Bousfield. 2001. The amphipod genus Allorchestes in the North Pacific region: systematics and distributional ecology. Amphipacifica 3(2): 3-37.

Hendrycks, E. A., and E. L. Bousfield. 2004. The amphipod family Pleustidae (mainly subfamilies Mesopleustinae, Neopleustinae, Pleusymtinae and Stenopleustinae) from the Pacific coast of North America: systematics and distributional ecology. Amphipacifica 3(4): 45-113.

Jarrett, N. E., and E. L. Bousfield. 1982. Studies on the amphipod family Lysianassidae in the Northeastern Pacific region. Hippomedon and related genera: Systematics and distributional ecology. National Museums of Canada, Publications in Biological Oceanography 10: 103-128.

Jarrett, N. E., and E. L. Bousfield. 1994a. The amphipod superfamily Phoxocephaloidea on the Pacific coast of North America. Family Phoxocephalidae. Part 1. Metharpiniinae, new subfamily. Amphipacifica 1(1): 58-140.

Jarrett, N. E., and E. L. Bousfield. 1994b. The amphipod superfamily Phoxocephaloidea on the Pacific coast of North America. Family Phoxocephalidae. Part II. Subfamilies Pontharpiniidae, Parharpiniinae, Brolginae, Phoxocephalinae, and Harpiniinae. Systematics and distributional ecology. Amphipacifica 1(2): 71-150.

Jarrett, N. E., and E. L. Bousfield. 1996. The amphipod superfamily Hadzioidea on the Pacific coast of North America: Family Melitidae. Part I. The Melita group: Systematics and distributional ecology. Amphipacifica 2(2): 3-74.

Laubitz, D. R. 1979. Phylogenetic relationships of the Podoceridae (Amphipoda, Gammaridea). Bulletin of the Biological Society of Washington 3: 144-152.

Laubitz, D. R. 1993. Caprellidea (Crustacea: Amphipoda): towards a new synthesis. Journal of Natural History 27: 965-976.

LeBlond, P. H., and E. L. Bousfield. 1995. Cadborosaurus, Survivor from the Deep. Horsdal and Schubart, Victoria, British Columbia, Canada. 
McLaughlin, P. A., D. K. Camp, M. V. Angel, E. L. Bousfield, P. Brunel, R. C. Brusca, A. C. Cohen, K. Conlan, L. G. Eldredge, D. L. Felder, J. W. Goy, T. Haney, B. Hann, R. W. Heard, E. A. Hendrycks, H. H. Hobbs III, J. R. Holsinger, B. Kensley, D. R. Laubitz, and S. E. Le. 2005. Common and scientific names of aquatic invertebrates from the United States and Canada: Crustaceans. American Fisheries Society Special Publication 31, Bethesda, Maryland, USA.

Mills, E. L. 1960a. Bird observations in the Queen Charlotte Islands, British Columbia. Canadian Field-Naturalist 74: 156-158.

Mills, E. L. 1960b. Heerman's Gull in Barkley Sound, British Columbia. Canadian Field-Naturalist 74: 162.

Mills, E. L. 1961. Amphipod crustaceans of the Pacific coast of Canada. I. Family Atylidae. National Museum of Canada Bulletin No. 172: 13-33.

Mills, E. L. 1962. Amphipod crustaceans of the Pacific coast of Canada. II. Family Oedicerotidae. Natural History Papers, National Museum of Canada 15: 1-21.

Rafi, F. 1985. Synopsis speciorum. Crustacea: Isopoda et Tanaidacea. Bibliographia Invertebratorum Aquaticorum Canadensium 4: 1-50.

Rafi, F., and D. R. Laubitz. 1990. The Idoteidae (Crustacea: Isopoda: Valvifera) of the shallow waters of the northeastern Pacific Ocean. Canadian Journal of Zoology 68: 2649-2687.

\section{Bibliography of Edward L. Bousfield}

Adapted from World Register of Marine Species (http://www .marinespecies.org/aphia.php? $p=$ sourcelist) with additions from other sources.

Bousfield, E. L. 1951. Pelagic Amphipoda of the Belle Isle Strait region. Journal of the Fisheries Research Board of Canada 8b: 134-163.

Bousfield, E. L. 1952. Zoological investigations in the Maritime provinces. Annual report of the National Museum of Canada 1950-1951. Bulletin of the National Museum of Canada 126: 188-194.

Bousfield, E. L. 1953. Studies on the shore fauna of the St. Lawrence estuary and Gaspé Coast. Canada Department of Northern Affairs and National Resources, Annual Report of the National Museum 136: 95-101.

Bousfield, E. L. 1955a. Ecological control of the occurrence of barnacles in the Miramichi estuary. Bulletin of the National Museum of Canada 137: 1-69.

Bousfield, E. L. 1955b. Some physical features of the Miramichi Estuary. Journal of the Fisheries Research Board of Canada 12: 342-361.

Bousfield, E. L. 1955c. The cirripede Crustacea of the Hudson Strait Region, Canadian Eastern Arctic. Journal of the Fisheries Research Board of Canada 12: 762-767.

Bousfield, E. L. 1956a. Malacostracan crustaceans from the shores of western Nova Scotia. Proceedings of the Nova Scotian Institute of Science 24: 1954-1958.

Bousfield, E. L. 1956b. Studies on the shore fauna of the St Lawrence estuary and Gaspe coast. Bulletin of the National Museum of Canada 136: 95-101.

Bousfield, E. L. 1956c. Studies on the shore Crustacea collected in eastern Nova Scotia and Newfoundland, 1954. Bulletin of the National Museum of Canada 142: 127-152.

Bousfield, E. L. 1957. Notes on the amphipod genus Orchestoidea on the Pacific coast of North America. Bulletin of the Southern California Academy of Sciences 56(3): 119129.

Bousfield, E. L. 1958a. Distributional ecology of the terrestrial Talitridae (Crustacea, Amphipoda) of Canada. Proceedings of the $10^{\text {th }}$ International Congress of Entomology 1: 883-898.

Bousfield, E. L. 1958b. Ecological investigations on shore invertebrates of the Pacific coast of Canada. Bulletin of the National Museum of Canada 147: 104-115.

Bousfield, E. L. 1958c. Fresh-water amphipod crustaceans of glaciated North America. Canadian Field-Naturalist 72: 55-113.

Bousfield, E. L. 1958d. Littoral marine arthropods and mollusks collected in western Nova Scotia, 1956. Proceedings of the Nova Scotia Institute of Science, 1956-1957 24: 303-325.

Bousfield, E. L., and A. H. Leim. 1959. The fauna of Minas Basin and Minas Channel. Bulletin of the National Museum of Canada 166: 1-30.

Porsild, A. E., and E. L. Bousfield. 1959. Frits Johansen 1882-1957. Canadian Field-Naturalist 73: 82.

Bousfield, E. L. 1960a. Canadian Atlantic Sea Shells. National Museum of Canada, Ottawa, Ontario, Canada.

Bousfield, E. L. 1960b. New records of beach hoppers (Crustacea, Amphipoda) from the coast of California. Bulletin of the National Museum of Canada 172: 1-24.

Bousfield, E. L. 1961. New records of fresh-water amphipod crustaceans from Oregon. Natural History Papers, National Museum of Canada 12: 1-7.

Bousfield, E. L. 1962a. New haustoriid amphipods from the Canadian Atlantic region. Bulletin of the National Museum of Canada 183: 63-75.

Bousfield, E. L., and D. E. McAllister. 1962b. Station list of the National Museum marine biological expedition to southeastern Alaska and Prince William Sound. National Museum of Canada Bulletin 183, Contributions to Zoology 1960-61, Biological Series 68: 76-103.

Bousfield, E. L. 1962c. Studies on littoral marine arthropods from the Bay of Fundy region. Bulletin of the National Museum of Canada 183: 42-62.

Bousfield, E. L. 1963a. A new freshwater amphipod crustacean from Oregon. Breviora 180: 1-6.

Bousfield, E. L. 1963b. New freshwater amphipod crustaceans from Florida. Natural History Papers, National Museum of Canada 18: 1-9.

Bousfield, E. L. 1964a. Coquillages des Côtes Canadiennes de l'Atlantique. Musée national du Canada. Ottawa, Ontario, Canada.

Bousfield, E. L. 1964b. Insects of Campbell Island. Talitrid amphipod crustaceans. Pacific Insects Monography 7: 45-57.

Bousfield, E. L. 1965. Haustoriidae of New England (Crustacea, Amphipoda). Proceedings of the United States National Museum 117: 159-239.

Bousfield, E. L., and J. Carlton. 1967. New records of Talitridae (Crustacea: Amphipoda) from the central California coast. Bulletin of the Southern California Academy of Sciences 66: 277-284.

Bousfield, E. L., and J. D. Hubbard. 1968. New records of gammaridean amphipod crustaceans from the intertidal zone of Prince William Sound, Alaska. National Museum of Canada Natural History Papers 40: 1-11.

Bousfield, E. L. 1969. New records of Gammarus (Crustacea, Amphipoda) from the middle Atlantic region. Chesapeake Science 10: 1-17. 
Bousfield, E. L., and L. B. Holthuis. 1969. Proposed use of the plenary powers for the suppression of the names proposed between 1814 and 1820 by C. S. Rafinesque for two genera and four species belonging to the order Amphipoda (Class Crustacea), and matters connected therewith. Z. N. (S.) 1879. Bulletin of Zoological Nomenclature 26: 105112.

Bousfield, E. L. 1970a. Adaptive radiation in sand-burrowing amphipod crustaceans. Chesapeake Science 11: 143-154.

Bousfield, E. L. 1970b. Terrestrial and aquatic amphipod Crustacea from Rennell Island. The Natural History of Rennell Island, British Solomon Islands 6: 155-168.

Howden, H. F., J. E. H. Martin, E. L. Bousfield, and D. E. McAllister. 1970. Fauna of Sable Island and its zoogeographic affinities - a compendium. National Museum of Canada Publications in Zoology 4: 1-45.

Bousfield, E. L., and J. W. Elwood. 1971. A new Gammarus (Crustacea, Amphipoda) from Tennessee. The American Midland Naturalist 85: 247-253.

Bousfield, E. L., and D. R. Laubitz. 1972. Station lists and new distributional records of littoral marine invertebrates of the Canadian Atlantic and New England region. National Museums of Canada, Publications in Biological Oceanography 5: 1-49.

Bousfield, E. L. 1973. Shallow-water Gammaridean Amphipoda of New England. Cornell University Press, Ithaca, New York, USA.

Bousfield, E. L. 1975. The spelling of the name Crangonychidae (Amphipoda). Crustaceana 29: 112

Bousfield, E. L. 1975a. Morphological key to Talitridae. Pages 352-355 in Light's Manual: Intertidal Invertebrates of the Central California Coast. Edited by R. I. Smith and J. T. Carlton. Third edition. University of California Press, Berkeley, California, USA.

Bousfield, E. L. 1975b. List of Talitridae. Pages 363-364 in Light's Manual: Intertidal Invertebrates of the Central California Coast. Edited by R. I. Smith and J. T. Carlton. Third edition. University of California Press, Berkeley, California, USA.

Bousfield, E. L., G. Filteau, M. O'Neill, and P. Gentes. 1975. Population dynamics of zooplankton in the middle St. Lawrence estuary. Pages 325-351 in Chemistry, Biology and the Estuarine System. Edited by L. E. Cronin. Estuarine Research 1. Academic Press, New York, New York, USA.

Bousfield, E. L., and M. L. H. Thomas. 1975. Postglacial changes in distribution of littoral marine invertebrates in the Canadian Atlantic region. Pages 47-60 in Environmental Change in the Maritimes. Edited by J. G. Ogden III and M. J. Harvey. A Symposium Sponsored by the Associate Committee for Quaternary Research, National Research Council, held at Dalhousie University, 22-23 October, 1971. Proceedings of the Nova Scotia Institute of Sciences 27 (Supplement 3).

Bousfield, E. L. 1976. A new terrestrial amphipod from Lord Howe Island (Parorchestia gowerensis n.sp). Records of the Australian Museum 30: 118-122.

Bousfield, E. L. 1977. A new look at the systematics of gammaroidean amphipods of the world. Crustaceana Supplement 4: 282-316.

Bousfield, E. L. 1978. A revised classification and phylogeny of amphipod crustaceans. Transactions of the Royal Society of Canada, Series 4 16: 343-390.

Bousfield, E. L. 1979a. The amphipod superfamily Gammaroidea in the northeastern Pacific region: systematics and distributional ecology. Bulletin of the Biological Society Washington 3: 297-357.

Bousfield, E. L. 1979b. Talitroidean amphipod crustaceans from the north American Pacific Coast, systematics and distribution ecology. Boletin Antartico Chileno.

Bousfield, E. L., and F. G. Howarth. 1979. The cavernicolous fauna of Hawaiian lava tubes 8. Terrestrial Amphipoda (Talitridae), including a new genus and species with notes on its biology. Pacific Insects Monography 17: 144-154.

Scudder, G. G. E., D. K. McE. Kevan, and E. L. Bousfield. 1979. Canada and its insect fauna. Part 3. Status of taxa in Canada. 7. Higher classification. Memoirs of the Entomological Society of Canada 111.S108: 235-240.

Bousfield, E. L. 1981a. Evolution in North Pacific coastal marine amphipod crustaceans. Evolution Today. Proceedings of the Second International Congress of Systematics and Evolutionary Biology: 69-89.

Bousfield, E. L. 1981b. Book review R313. British Marine Amphipoda: Gammaridea (Roger J. Lincoln. British Museum (Natural History), London. 1979. 657 pages). Canadian Journal of Fisheries and Aquatic Sciences 38: 732-733.

Bousfield, E. L., and J. R. Holsinger. 1981. A second new subterranean amphipod crustacean of the genus Stygobromus (Crangonyctidae) from Alberta, Canada. Canadian Journal of Zoology 59: 1827-1830

Bousfield, E. L., and N. E. Jarrett. 1981. Station lists of marine biological expeditions of the National Museum of Natural Sciences in the North American Pacific Coastal region, 1966 to 1980 . Syllogeus 34: 1-66.

Bousfield, E. L. 1982a. The amphipod superfamily Talitroidea in the North-eastern Pacific region. I. Family Talitridae: Systematics and distributional ecology. National Museums of Canada, Publications in Biological Oceanography 11: $1-77$.

Bousfield, E. L. 1982b. Amphipoda. Pages 254-294 in Synopsis and Classification of Living Organisms. Edited by S. P. Parker. McGraw-Hill, New York, New York, USA.

Bousfield, E. L. 1982c. Amphipoda (Palaeohistory). McGrawHill Yearbook of Science and Technology, 1982-1983: 96-100.

Bousfield, E. L. 1982d. Peracarida. Page 241 in Synopsis and Classification of Living Organisms. Edited by S. P. Parker. McGraw-Hill, New York, New York, USA.

Bousfield, E. L., and N. L. Tzvetkova. 1982. K izucheniju Dogielinotidae (Amphipoda, Talitroidea) iz pribrezhnykh vod severnoj chasti Tikhogo okeana [Studies on Dogielinotidae (Amphipoda, Talitroidea) from the shallow waters of the North Pacific Region]. Issledovanija Fauny Morej / Zoologicheskij Institut, Akademija Nauk SSSR 29(37): 76-94.

Conlan, K. E., and E. L. Bousfield. 1982a. The amphipod superfamily Corophioidea in the Northeastern Pacific region. Family Ampithoidae: systematics and distributional ecology. National Museum of Natural Sciences (Ottawa). Publications in Biological Oceanography 10: 41-75.

Conlan, K. E., and E. L. Bousfield. 1982b. The amphipod superfamily Corophioidea in the Northeastern Pacific region. Family Aoridae: systematics and distributional ecology. National Museum of Natural Sciences (Ottawa). Publications in Biological Oceanography 10: 77-101.

Jarrett, N. E., and E. L. Bousfield. 1982. Studies on the amphipod family Lysianassidae in the Northeastern Pacific region. Hippomedon and related genera: systematics and distributional ecology. National Museums of Canada, Publications in Biological Oceanography 10: 103-128. 
Soper, J. H., and E. L. Bousfield. 1982. A tribute to William Kirwan Willcocks Baldwin, M. B. E. (1910-1979). Canadian Field-Naturalist 96: 92-97.

Bousfield, E. L. 1983a. An updated phyletic classification and palaeohistory of the Amphipoda. Pages 257-277 in Crustacean Issues 1: Crustacean Phylogeny. Edited by F. R. Schram. Balkema, Rotterdam, Netherlands.

Bousfield, E. L. 1983b. Une carrière consacrée aux Amphipodes. Echo, National Museum of Canada 3(5): 1-2.

Conlan, K. E., and E. L. Bousfield. 1983. The amphipod superfamily Corophioidea in the northeastern Pacific Region. Family Isaeidae: systematics and distributional ecology. National Museum of Canada, Publications in Natural Sciences 4: 1-75.

Bousfield, E. L. 1984a. Recent advances in the systematics and biogeography of landhoppers (Amphipoda: Talitridae) of the Indo-Pacific Region. Pages 171-210 in Biogeography of the Tropical Pacific. Edited by F. J. Radovsky, P. H. Raven, and S. H. Sohmer. Association of Systematics Collections and the Bernice P. Bishop Museum as Bishop Museum Special Publication 72.

Bousfield, E. L. 1984b. The phyletic ordering of major character states as a basis for natural classification of the Amphipoda. Amphipod Phylogeny Workshop, Ottawa, 1708-1984.

Bousfield, E. L. 1985. Mysterious insects of the sea. Rotunda, the magazine of the Royal Ontario Museum 18: 30-36.

Bousfield, E. L., and R. W. Heard. 1986. Systematics, distributional ecology and some host-parasite relationships of Uhlorchestia uhleri (Shoemaker) and U. spartinophila, n.sp. (Crustacea, Amphipoda), endemic to salt marshes of the Atlantic Coast of North America. Journal of Crustacean Biology 6: 264-274.

Bousfield, E. L. 1987. Amphipod parasites of fishes of Canada. Canadian Bulletin of Fisheries and Aquatic Sciences 217: 1-37.

Bousfield, E. L., and Z. Kabata. 1987. Amphipoda. Pages 149-163 in Guide to the Parasites of Fishes of Canada. Edited by L. Margolis and Z. Kabata. Special Publication of Fisheries and Aquatic Sciences 101. Department of Fisheries and Oceans, Ottawa, Ontario, Canada.

Halcrow, K., and E. L. Bousfield. 1987. Scanning electron microscopy of surface microstructures of some gammaridean amphipod crustaceans. Journal of Crustacean Biology 7: 274-287.

Bousfield, E. L. 1989. Revised morphological relationships within the amphipod genera Pontoporeia and Gammaracanthus and the "glacial relict" significance of their postglacial distributions. Canadian Journal of Fisheries and Aquatic Sciences 46 : 1714-1725.

Bousfield, E. L., and J. R. Holsinger. 1989. A new crangonyctid amphipod crustacean from hypogean fresh waters of Oregon. Canadian Journal of Zoology 67: 963-968.

Bousfield, E. L. 1990. A new genus and species of hadzioidean amphipod crustacean from anchialine pools in Hawaii. Beaufortia 41(4): 25-30.

Bousfield, E. L., and K. E. Conlan. 1990. Crustaceans: subphylum Crustacea. Pages 840-859 in The New Encyclopaedia Britannica. Encyclopædia Britannica, Inc, USA.

Bousfield, E. L. 1991. New sandhoppers (Crustacea: Amphipoda) from the Gulf Coast of the United States. Gulf Research Reports 8: 271-283.

Bousfield, E. L. 1992. Sea monsters in Western Canada. Sea Wind 6: 29-33.
Bousfield, E. L., and H. Morino. 1992. The amphipod genus Ramellogammarus in fresh waters of western North America: systematics and distributional ecology. Contributions to Natural Science 17: 1-21.

Bousfield, E. L., and E. A. Hendrycks. 1994a. A revision of the family Pleustidae (Amphipoda: Gammaridea). Part 1. Systematics and biogeography of component subfamilies. Amphipacifica 1: 17-57.

Bousfield, E. L., and E. A. Hendrycks. 1994b. The Amphipod superfamily Leucothoidea on the Pacific coast of North America. Family Pleustidae: Subfamily Pleustinae. Systematics and Biogeography. Amphipacifica 1: 3-69.

Bousfield, E. L., and J. A. Kendall. 1994. The amphipod superfamily Dexaminoidea on the North American Pacific Coast; Families Atylidae and Dexaminidae: systematics and distributional ecology. Amphipacifica 1: 3-66.

Bousfield, E. L., and C.-T. Shih. 1994. The phyletic classification of amphipod crustaceans: problems in resolution. Amphipacifica 1: 76-134.

Bousfield, E. L., and C. P. Staude. 1994. The impact of J. L. Barnard on North American Pacific amphipod research: a tribute. Amphipacifica 1: 3-16.

Jarrett, N. E., and E. L. Bousfield. 1994a. The amphipod superfamily Phoxocephaloidea on the Pacific coast of North America. Family Phoxocephalidae. Part 1. Metharpiniinae, new subfamily. Amphipacifica 1: 58-140.

Jarrett, N. E., and E. L. Bousfield. 1994b. The amphipod superfamily Phoxocephaloidea on the Pacific coast of North America. Family Phoxocephalidae. Part II. Subfamilies Pontharpiniidae, Parharpiniinae, Brolginae, Phoxocephalinae, and Harpiniinae. Systematics and distributional ecology. Amphipacifica 1: 71-150.

Bousfield, E. L. 1995. A contribution to the natural classification of Lower and Middle Cambrian arthropods: foodgathering and feeding mechanisms. Amphipacifica 2: 334

Bousfield, E. L., and E. A. Hendrycks. 1995a. The amphipod family Pleustidae on the Pacific Coast of North America. Part 3. Subfamilies Parapleustinae, Dactylopleustinae and Pleusirinae: systematics and distributional ecology. Amphipacifica 2: 65-133.

Bousfield, E. L., and E. A. Hendrycks. 1995b. The amphipod superfamily Eusiroidea in the North American Pacific region. 1. Family Eusiridae: systematics and distributional ecology. Amphipacifica 1: 3-59.

Bousfield, E. L., and P. M. Hoover. 1995. The Amphipod superfamily Pontoporeioidea on the Pacific Coast of North America. II. Family Haustoriidae. Genus Eohaustorius J. L. Barnard: systematics and distributional ecology. Amphipacifica 2: 35-64.

Bousfield, E. L., and P. H. Leblond. 1995. An account of Cadborosaurus willsi, new genus, new species, a large aquatic reptile from the Pacific coast of North America. Amphipacifica 1(Suppl. 1): 3-25.

Bousfield, E. L., and G. O. Poinar Jr. 1995. New terrestrial amphipod from Tertiary amber deposits of the Dominican Republic. Journal of Crustacean Biology 15: 746-755.

LeBlond, P. H., and E. L. Bousfield. 1995. Cadborosaurus, Survivor from the Deep. Horsdal and Schubart, Victoria, British Columbia, Canada.

Bousfield, E. L. 1996a. A contribution to the reclassification of Neotropical freshwater hyalellid amphipods (Crustacea, Gammaridea, Talitroidea). Bolletino del Museo Civico di Storia Naturale di Verona 20: 175-224. 
Bousfield, E. L. 1996b. The amphipod superfamily Hadzioidea on the Pacific coast of North America. Part 1. The Melita group: systematics and distributional ecology. Amphipacifica 2: 1-73.

Bousfield, E. L., and A. Chevrier. 1996. The amphipod family Oedicerotidae on the Pacific Coast of North America. 1. The Monoculodes and Synchelidium generic complexes: systematics and distributional ecology. Amphipacifica 2: 75-148.

Jarrett, N. E., and E. L. Bousfield. 1996. The amphipod superfamily Hadzioidea on the Pacific coast of North America: Family Melitidae. Part I. The Melita group: systematics and distributional ecology. Amphipacifica 2: 3-74.

Bousfield, E. L., and E. A. Hendrycks. 1997. The amphipod superfamily Eusiroidea in the North American Pacific Region. 2I. Family Calliopiidae. Systematics and distributional ecology. Amphipacifica 2: 3-66.

Bousfield, E. L., and P. M. Hoover. 1997. The amphipod superfamily Corophioidea on the Pacific Coast of North America. Part V. Family Corophiidae: Corophiinae, new subfamily. Systematics and distributional ecology. Amphipacifica 2: 67-139.

Bousfield, E. L. 1998. The scientific search for aquatic megaserpents. Amphipacifica 3: 1-16.

Margolis, L., T. E. Mcdonald, and E. L. Bousfield. 2000. The whale lice (Amphipoda: Cyamidae) of the Northeastern Pacific region. Amphipacifica 2: 63-117.

Bousfield, E. L. 2001a. An updated commentary on phyletic classification of the amphipod Crustacea and its application to the North American fauna. Amphipacifica 3: 49-119.

Bousfield, E. L. 2001b. Biogeographical analysis of gammaridean amphipod faunas based on their phyletic classification. Polskie Archiv fuer Hydrobiologie 47: 335-352.

Bousfield, E. L. 2001c. The genus Anisogammarus (Gammaroidea: Anisogammaridae) on the Pacific coast of North America. Amphipacifica 3: 29-48.

Hendrycks, E. A., and E. L. Bousfield. 2001. The amphipod genus Allorchestes in the North Pacific region: systematics and distributional ecology. Amphipacifica 3: 3-37.

Hoover, P. M., and E. L. Bousfield. 2001. The amphipod superfamily Leucothoidea on the Pacific coast of North America: Family Amphilochidae: systematics and distributional ecology. Amphipacifica 3: 3-28.

Bousfield, E. L., and E. A. Hendrycks. 2002. The talitroidean amphipod family Hyalidae revised, with emphasis on the North Pacific fauna: systematics and distributional ecology. Amphipacifica 3: 17-134.
Krapp-Schickel, T., and E. L. Bousfield. 2002. The talitroidean amphipod genus Hyale Rathke, 1837, sens. str. in the North Atlantic and Mediterranean regions. Amphipacifica 3: 1-14.

Bousfield, E. L., and P. Marcoux. 2004. The talitroidean amphipod family Najnidae in the North Pacific region: systematics and distributional ecology. Amphipacifica 3: 3-44.

Dyke, A. S., D. A. Hodgson, E. L. Bousfield, and R. E. Bedford. 2004. A tribute to Victor Kent Prest 1913-2003. Canadian Field-Naturalist 118: 626-629.

Hendrycks, E. A., and E. L. Bousfield. 2004. The amphipod family Pleustidae (mainly subfamilies Mesopleustinae, Neopleustinae, Pleusymtinae and Stenopleustinae) from the Pacific coast of North America: systematics and distributional ecology. Amphipacifica 3: 45-113.

McLaughlin, P. A., D. K. Camp, M. V. Angel, E. L. Bousfield, P. Brunel, R. C. Brusca, A. C. Cohen, K. Conlan, L. G. Eldredge, D. L. Felder, J. W. Goy, T. Haney, B. Hann, R. W. Heard, E. A. Hendrycks, H. H. Hobbs III, J. R. Holsinger, B. Kensley, D. R. Laubitz, and S. E. Le. 2005. Common and Scientific Names of Aquatic Invertebrates from the United States and Canada: Crustaceans. American Fisheries Society Special Publication 31, Bethesda, Maryland, USA.

Bousfield, E. L. 2007a. Talitridae. Pages 611-613 in The Light and Smith Manual: Intertidal Invertebrates from Central California to Oregon. Completely Revised and Expanded. Edited by J. T. Carlton. Fourth edition. University of California Press, Berkeley, California, USA.

Bousfield, E. L. 2007b. List of species. Page 614 in The Light and Smith Manual: Intertidal Invertebrates from Central California to Oregon. Completely Revised and Expanded. Edited by J. T. Carlton. Fourth edition. University of California Press, Berkeley, California, USA.

Bousfield, E. L. 2011. On the occurrence of Cadborosaurus in Clayoquot Sound based on a native artist illustration. Letters. B. C. Magazine, fall issue, 211.

Bousfield, E. L. 2012. Regarding Donald Ainslie's installation speech concerning the staircase "chimera". Letters. UC Alumni Magazine, fall issue, 2012: 6.

Bousfield, E. L., and F. R. Cook. 2012. A tribute to Charles Hogg Douglas, 1923-2004. Canadian Field-Naturalist 126 : 164-166.

Received 16 January 2017

Accepted 20 February 2017 